\title{
Accrual Accounting in Public Sectors: \\ Possible Contextual and Application Gaps for Future \\ Research Agenda
}

\author{
Rozaidy Mahadi \\ Universiti Malaysia Sabah \\ Siti Nabiha Abdul Khalid \\ Universiti Sains Malaysia \\ Rasid Mail \\ Universiti Malayia Sabah \\ Raman Noordin \\ Universiti Malaysia Sabah
}

$\begin{array}{ll}\text { Received: March 21, } 2017 & \text { Accepted: April 11, } 2017 \quad \text { Published: June 1, } 2017 \\ \text { doi:10.5296/ajfa.v9i1.10968 } & \text { URL: https://doi.org/10.5296/ajfa.v9i1.10968 }\end{array}$

\begin{abstract}
This paper analyses the possible contextual and application gaps derived from the utilisation of van Helden and Northcott's (2010) method of study for classifying themes in published public sector's accrual accounting papers according to their research objectives. As a result, our theme categorisation refers to the following research objectives: a) proposing new financial/management accounting techniques/approaches for public sector accrual accounting systems (e.g. accrual output-based budgeting, performance management and costing); b) examining the effectiveness of accrual accounting techniques/approaches; c) identifying the conditions for the successful/failure of the implementation of accrual accounting techniques/approaches; and d) knowledge-building in understanding, explaining and critiquing the adoption and use of accrual accounting techniques/approaches, both theoretically and practically. Through the process of populating and establishing the themes
\end{abstract}




\section{Macrothink

(based on research objectives), we were able to identify which areas of study have received less attention and which areas have room for further exploration.

Keywords: Public Sector Accounting, Accrual Accounting, Future Research 


\section{Introduction}

Within the world of public sector accounting, a distinct movement, the new public management (NPM) paradigm (Hood, 1995), has had a profound effect on accounting practices. The NPM is a model of reform that favours quantification and results and in which accounting has a central role. One of the by-products of this movement is accrual-based accounting systems, which arguably provide better efficiency and transparency tools with regard to enhancing financial management and controls. Many governments have adopted these accounting systems (Pallot, 1998).

Chile was the first state to introduce accrual accounting for the public sector in the early 70 s, followed by New Zealand in 1990. Unlike other countries, New Zealand changed its systems comprehensively. However, other countries such as the USA and Australia switched to accrual accounting in 1997, but only in central governmental administration, with changes in local administration being implemented several years later. By the turn of the year 2000, New Zealand had become one of the countries with the most extensive set of accrual accounting disclosures (Ellwood \& Newberry, 2007). Subsequently, other countries gradually followed suit, especially OECD countries and those that had a similar motive, to reform the financial management systems in the public sector.

Whilst the adoption of accrual accounting was embraced by the various levels of public sector organisations under the umbrella of NPM, research pertaining to accrual accounting in the public sector increased and enriched the body of knowledge in public sector accounting literature. Among the popular themes in this area of research are: 1)proposing new financial/management accounting techniques/approaches into public sector accrual accounting systems (e.g. accrual output-based budgeting, performance management and costing); 2) the effectiveness of accrual accounting techniques and approaches; 3 ) identifying the conditions for the successful implementation of accrual accounting technique/approaches; and 4) knowledge-building in terms of understanding, explaining and critiquing the adoption and use of accrual accounting techniques/approaches, both theoretically and practically.

Those strong research-practice nexus offer important benefits to researchers, since the acknowledgement of their academic pursuits is enhanced by investigating relevant issues that contribute to the solution of practical problems and/or serve the interest of research stakeholders. These stakeholders are governments, policy-makers, accounting practitioners and business managers. The appropriate identification of plausible research gaps and/or outcomes benefits research and academic communities, and therefore forms the focus of this paper.

The remainder of the paper is structured as follows. First, we draw on van Helden and Northcott's (2010) method for classifying themes in published public sector accrual accounting papers according to their research objectives. The selection of academic journals and the classification procedure adopted are also explained. Next, we elaborate on key issues from identified themes extracted from the reviewed papers. Finally, we discuss the findings and reflect on their implications for future research gaps in the development of accrual accounting research in the public sector. 


\section{Research Method: Classifying Themes}

In this study, van Helden and Northcott's (2010) method of study will be employed to classify the relevant and accurate themes in published public sector accrual accounting research articles. To identify and classify the relevant themes, van Helden and Northcott (2010) started the process by looking at the research objectives underlying public sector management accounting research (PSMAR) articles in the period from 1990 to 2005 in five prominent journals After that, they examined the extent to which the reviewed papers highlighted the practical implications of their research. Consequently, the main focus of their findings was on the aspects of practical relevance in the research aims and content, and the communication of practice-relevant findings. From these two main focus areas, they developed and categorised four main themes out of the 128 papers that they examined.

Even though this study has adapted van Helden and Northcott's four themes, there is a slight difference between our study and that of van Helden and Northcott (2010), and this needs to be addressed. First, there is a difference in research focus; van Helden and Northcott's study focused on the area of public management accounting research. Therefore, when generating the themes they reviewed articles covering a broad range of management accounting research realms in the public sector, including accrual accounting based research papers. Consequently, a total of 128 papers were reviewed to plot the themes. Meanwhile, our study focus is limited to research papers related to the area of accrual accounting in public sectors. Thus, our reviewed papers numbered only 50 articles, which are primarily accrual accounting based research papers. However, this difference does not critically impair the adaption of van Helden and Northcott's thematic system since their study substantively covers a majority of accrual accounting based research papers. As a result, our themes categorisation refers to the following research objectives:

A. Proposing new financial/management accounting techniques/approaches for public sector accrual accounting systems (e.g. accrual output based budgeting, performance management and costing);

B. Examining the effectiveness of accrual accounting techniques/approaches;

C. Identifying the conditions for the successful/failure implementation of accrual accounting technique/approaches;

D. Knowledge-building in understanding, explaining and critiquing the adoption and use of accrual accounting techniques/approaches, both theoretically and practically.

To arrive at the above-mentioned objectives, we followed van Helden and Northcott's (2010) method for selecting journal articles for the reviewing process. The selection of the journals was based on papers published in high-quality international accounting journals with an interest in accrual accounting in the public sector. Our review included a total of 50 papers published in the 1992-2012 volumes of Accounting, Auditing \& Accountability Journal (AAAJ); Accounting, Organizations \& Society (AOS); British Accounting Review (BAR); 
Critical Perspectives on Accounting (CPA); European Accounting Review (EAR); Financial Accountability and Management (FAM); Management Accounting Research (MAR); and Accounting History. The process continued with an examination of the extent to which the reviewed papers highlighted the practical/theoretical implications of their research (see Appendix 1). Consequently, the first part of the examination process started with identifying the research's aims and content, while the second part of the process concerned the communication of their theoretical contribution and suggestions for future research. In addition, in order to classify the theme criteria and identify the research gaps, we developed categorisation schemes around these two focus areas.

Moreover, as shown in Appendix 1, the analysis revealed that the majority of the reviewed papers have a combination of two or more research objectives. For example, Adhikari and Mellemvil (2011) in their paper 'The rise and fall of accrual: a case of Nepalese central government', combined two research objectives: one as a main focus (D), and one complimentary research objective (B). Another example is Christianes' (2001) study, which has a combination of more than two research objectives: research objective (D) as a backbone of the study, complimented by two other research objectives (A) and (B). Based on our analysis, the majority of the articles were constructed around or incorporated two main themes (research objectives D \& B). This trend shows that most scholars are interested in the explanation and examination of the implementation of accrual accounting in the public sector.

With that fundamental component in mind, through the process of populating and establishing the themes (based on the research objectives), we were able to identify which areas of studies have received less attention and which areas have room for further exploration. For example, the studies that have concentrated on research objective $\mathrm{C}$ have often neglected the advantage of conducting comparative studies between various governmental agencies. As a result, we know only a little about the impact of variations in governmental structures (e.g. organisational structure, legislation frameworks and financial procedures) when the financial reforms take place at different levels of governmental agencies (i.e. between the federal and state level). The detail will be further explained in the next section. We adhered to the gap identification process suggested by the reviewed authors. Finally, from the reviewed articles we have identified three research gaps that hopefully can be addressed as a focus for future research:

A. More research on accrual accounting development research in developing countries' public sectors.

B. The importance of cross-sectional or comparative studies.

C. Exploration of historical studies of accrual accounting and financial management practices in varied public sector contexts.

\section{Research Themes in Accrual Accounting in the Public Sector}

\subsection{Analysis of Research Objectives A \& B}

NPM has become a popular research paradigm in public sector accounting. The migration of 
accounting systems from conventional cash to an accrual basis has driven the introduction of new accounting techniques that meet the changing needs and opportunities. In the case of accrual accounting in the public sector, new financial/management accounting techniques (e.g. for output-based budgeting, financial accounting standards or performance measurement) have been proposed as tools to improve the functioning of the public sector's financial management. Changes in the public sector's accounting systems offer new ground for scholars to explore new techniques and approaches with the target of enriching the application of accrual accounting techniques in the public sector. As a result, the study of the development of new accounting techniques and approaches in public sector accounting has become one of the main research objectives among scholars in this field.

For instance, Luder (2000) examined Systems of National Accounts (SNA) and the European Systems of Accounts (ESA) in order to identify the weaknesses of the current EMU-procedures for determining governments' financial conditions and suggesting solutions. Luder suggested that EMU members should design an appropriate definition for government's debt and deficit ratios to secure reliable measurement when comparing cross-country (European) governments' financial conditions. Luder's (2000) paper provides an example of research objective A, which was uncommon in our review. This was commented on by van Helden (2005) when he explained why few researchers have taken this subject as their main research theme, 'the authors in public sector accounting mainly stick to their academic background and seem to take a rather distant stand from practice'. Moreover, accrual accounting itself is not an alien or totally new practice since it has been widely practised in private sectors and commonly studied by scholars. In addition, the application of accrual accounting techniques or approaches in the public sector was largely adapted and adopted from the accrual accounting systems practised in the private sector. Thus, research in this area offers limited room for new discoveries and consequently attracts less attention from scholars.

Despite that, the introduction of new policies or systems in government sectors is commonly welcomed with debates, the aim of which is to predict the expected prospects and negative effects on government performances in the future. The same treatment was applied when the accrual accounting systems were introduced as a new accounting system, replacing the old cash basis systems. The introduction received a mixed acceptance among public sector accounting scholars. Since the functioning of conventional accounting (cash basis) had been criticised for several decades, accrual accounting techniques/approaches were argued to be a means of elevating governments' poor financial management, as well as an effective mechanism for supervising public sector financial practices. Thus, in order to examine these proposed results, many scholars have embarked on research studies to evaluate the effectiveness of this new accounting practice with regard to public sector financial performances. Hence, this research focus has been identified as a Research Objective B in our study, and based on our analysis, this is the second most popular subject of research among public sector accounting scholars.

An example of this type of research objective is as follows. Mellet and Howard (1997) sought to examine the consequences of adopting a more business-like approach (NPM agenda) as 
part of the reform of the National Health Systems (NHS) in Wales, following the early 1990's reforms of the U.K.'s healthcare systems. Their research emphasised the role of the accounting process, using the experience of NHS trust hospitals in Wales to illustrate the impact of the changes on hospital performance, especially in financial terms. Meller and Howard (1997) highlighted several constraints faced by public sector organisations when applying private sector practices to their financial systems, such as a vague conceptual framework for recognising profit/surplus between cash accounting and accrual accounting, which impairs the NHS's financial accountability representation.

Another example is Newberry and Pallot's (2005) study, which undertakes an interrogation of the New Zealand government's financial systems. It examines New Zealand's financial legislation and assesses the implications for democracy of the form of parliamentary control over the use of taxpayers' funds. The study raised an issue regarding the auditor general's controller function, which has been impaired by the changes and financial reforms of 1988/89. The authors also argued that accrual-based financial reporting creates wonderful opportunities for hiding problems, as the collapses of Enron and Parmalat have shown. Other papers dealing with this type (B) research objective are commonly explored in New Zealand's, Australia's and the U.K's public sector organisations (e.g. Christianes and Wielmaker, 2003; Marti, 2006; Hoque, 2001).

However, there are several areas of studies connected with research objective B that have received less attention from scholars, and further investigation should be carried out to address the gaps in these areas of studies. Studies that focus on research objective B, which is examining the effectiveness of accrual accounting practices, mostly concentrate on developed countries, and less research is focused on developing countries (for exceptions, see Adhikari \& Mellemvik,2011; Harun \& Eggleton, 2012). In recent years, many developing countries have declared various NPM reforms, although these efforts are still underrepresented with regard to research publications (Graham, 2009). More studies are needed in this context since the experiences of developing nations are bound to be different from highly developed governments with rich administrative traditions, such as Hong Kong.

In general, the migration to accrual accounting in developed countries follows the same movement in developing countries. However, financial reforms in developing countries were driven by the requirement to abide by the rules commanded by their financial creditors or donors, such as the International Monetary Fund (IMF), the World Bank and the Asian Development Bank (Adhikari \& Mellemvik, 2011). In this case, New Zealand in particular has been regarded as highly successful in its accrual accounting implementation, and has frequently became a proposed template to be copied by international creditors with regard to their borrowers (Bale \& Dale, 1998).

Exemplary to this situation is the study conducted by Harun et al. (2012) which shows that the institutionalisation of accrual accounting ideas and practices in Indonesia was extensively issued and disseminated by international organisations and donors. Similar situations also occurred in Nepal (Adhikari \& Mellemvik, 2011), where the changes towards accrual accounting were motivated by international donors. Despite the increasing appeal of accrual 
accounting and its wide ranging implications for the role and functioning of public sector accounting systems, there has been comparatively little study of its application and impacts in developing countries. The scarcity of literature on this subject in developing countries is due to the fact that the development of accrual accounting in these countries is still in its infant stage, compared to developed countries which have reached their peak maturity level. Thus, research into this concern is also still in its infancy stage, and we consequently know relatively little about the issues related to accrual accounting practices in developing countries (Jones \& Kettl, 2003).

Moreover, lack of research in this context provides greater opportunity to explore and examine the implementation process of accrual accounting at a national level in developing countries. For example, the Malaysian government reportedly aims to implement comprehensive accrual accounting systems at all federal level ministries by 2016 and the effort will be extended to state government in the following year (Pasukan Pelaksanaan Perakaunan Akruan, 2015). The same initiative has been followed by Brazil (2013), Nigeria (2016) and according to PwC (2015), 29 developing countries will be expected to adopt accrual accounting systems at a federal level by 2018. This is good evidence of attempts to broaden the remit of public sector accounting research in order to consider a wider range of organisations (Broadbent and Guthrie, 2007; Guthrie, 1998), even though, as noted earlier, scholars are still attracted to studies at a local administration level. The opportunity to study diverse locations and undertake comparisons, especially among developing countries, should be grasped as it provides the basis for contrast and comparison, which facilitate our learning and allow both the transfer of good practices and the prevention of mistakes being repeated.

In addition, it is worth mentioning a few other areas of research that can be considered contextually relevant, since this kind of study is familiar in developed countries but practically new in developing countries. Firstly, there is the accountability and auditing issue; it is significantly relevant but less attention has been given to this area of study. Based on our review, most of the studies related to the subject of public accounting reforms in developing countries have concentrated on the readiness, standard setting and evaluation of the development of accrual accounting systems. The adoption of accrual accounting systems has altered the public sector's legal and administration framework and subsequently affected its governing and auditing systems (English, 2003a). Thus, accountability and auditing issues in the context of developing countries are undoubtedly significant and merit further investigation. Secondly, studying government policy and execution plans (i.e. the implementation of accrual accounting systems) and comparing them with the outcomes is empirically important. It enables us to compare and contrast the planning and outcomes, therefore the findings generated from this process will help to prevent counterproductive results and also determine effective mechanisms to enhance organisational strategies.

The third area of study in this context that requires more attention is in the area of management control systems, especially in accounting information systems (AIS). Changes in accounting information systems commonly occur when governments change their 
accounting practices (Luder, 1994; Harun et al., 2012). Thus, it is crucial to investigate the new accounting information systems that have been put in place. However, this area of study has also received less attention; as argued by Yamamoto (2009), there are few studies about how control systems work and why they have persisted in the public sector. As Goddard (2010) has emphasised, we need to know much more about how accounting and financial management reforms work in developing countries, where issues of auditing and governance may play different roles than in developed nations.

\subsection{Analysis of Research Objectives C \& D}

Research D types can be directed at explaining, understanding and critiquing the motivations behind (and/or outcomes of) the adoption and use of accrual accounting techniques/approaches. Such studies tend to reconfirm or object to the analysis advocated by prominent authors, such as Guthrie (1998), Pallot (1999), Mellet (1997) and Pollitt (2002). Most research in this area has tried to be more critical in its analysis of the adoption of accrual accounting techniques/approaches in various organisational contexts, and to not bluntly favour the idealistic conceptions of accrual accounting practices put forward by NPM advocators such as politicians and the IMF. The critical examination of how and why accrual accounting techniques/approaches are used in public sector contexts and the outcomes (intended and unintended) of their use, therefore presents a fourth agenda for research that builds knowledge to inform future research practice/theoretical developments.

Studies directed at understanding the use of accrual accounting techniques/approaches (research objective D) are mainstream in our review. The theoretically oriented studies mostly discuss how technical accounting is applied, including the organisational and contextual factors that influence their applications (see, for example, Newberry and Pallot, 2005; Barton, 2004; Pallot, 2001). In general, most studies that fall under this category are mainly reflective in nature - that is, they tend to critically examine the development and application of accrual accounting techniques/approaches by indirectly defined theoretical explanation (see, for example, Potters, 2002; Garseth, 2011; Brorstrom, 1998). Below are two examples of research objective D type of studies.

Potters' (2002) study discusses how technical accounting is used to understand financial accounting reforms in public sector organisations. Potters explores the forces at work in shaping the recent innovation in Australian public sector financial accounting reforms. He pins the research findings to Douglas's institutional thinking in understanding the connection between the preparation of a conventional accounting report and the improvement in the accountability and performance of diverse public sector entities. Douglas's theory suggested that institutions are primarily denoted by their role in shaping the thinking of associated individuals. The theory also postulates that societies and cultures develop legitimised social groupings such as families, or legitimised social processes such as games or ceremonies. Douglas refers to these legitimised groups or processes as an "institution". The study found that the commercial accounting framework has been influential in shaping the nature of content of recent accounting reforms in the Australian public sectors.

Bogt's (2008) study examines accounting change from an institutional point of view. The 
study focuses on the various possible reasons for their introduction, change process and the effect of the changes on the Dutch public sector. To encapsulate the explanations, Bogt uses Burns and Scapen's (2000) framework for accounting change. Bogt's (2008) research indicates that economic issues, such as budgetary pressures, played a role in the introduction of various accounting changes. Further, several changes were introduced because they were a 'success' elsewhere, in order to look 'modern', because they were expected by certain stakeholders, or because they have mandated. The underpinning theory indicates that accounting change in the Dutch public sector, driven by the organisational culture, which is closely related to the internal institutions, might be an important effect of management accounting changes and those changes will gradually become routines and institutions. Hence, Bogt's (2008) study showcased how a certain theory was chosen to examine the development and use of accrual accounting techniques/approaches in public sector organisations.

Finally, the fourth research objective (research objective C) relates to identifying the conditions of the success/failure of accrual accounting techniques and approaches. The reviewed articles reveal that the successful criteria for introducing new accounting techniques/approaches in public sectors depend not only on the organisation's ability to identify appropriate techniques, but also on behavioural issues, such as a good match between various controls, organisational cultures, and attention paid to the recruitment and training of employees (e.g. Nepworth, 2003; Robinson, 1998; Lye et al., 2005). Based on the analysis, classifying the conditions that support successful implementation is a common research objective among scholars. Furthermore, research objective $\mathrm{C}$ was commonly chosen as a complimentary focus by scholars and seldom stood as the main focus of their study. Research objective $\mathrm{C}$ is mostly complimented either with research objectives B or D.

For instance, when the scholar tries to build a theoretical explanation and understanding of the adoption of accrual accounting techniques/approaches (research objective D) in particular organisations, the study starts with identifying the conditions or factors that explainthe phenomena studied. For example, Christianes' (2002) study examines the process of change in the New South Wales government's early adoption of accrual-based financial reporting (research objective D). In his study, Christianes revisited an analytic framework that is a proposed variant of Luder's (1994) contingency model, and presented five hypotheses (see Christianes, 2002) for testing the revised model. Christianes argued that individual factors should be incorporated in explanations of public sector accounting change. The study also acknowledged the existence of other factors in explaining the process of accounting change in the New South Wales government. The study unveiled poor management control systems, inadequate accounting skills and poor asset records as the factors that paved the way for the hypotheses to expound the theoretical construction. Thus, this illustration shows that the identification of factors/conditions (research objective C) is habitually designed as a complimentary focus in the process of discussing the main focus of the study (in this example, research objective D).

Whilst many theoretical and practical explanations have been constructed at various contextual domains in studies associated with accrual accounting practices in the public sector, fewer studies have selected cross-sectional or comparative methods as the base of 
their study, and most studies frequently choose national, state, local and governmental agencies as their contextual bases. Cross-sectional and comparative study between different levels of governmental agencies is crucial because each level of government has a different set of political and administration systems. For instance, in the U.K., the formation of three different states (Wales, England and Northern Ireland) has separated the power between state government, local government, and central government. Therefore, transnational or cross-sectional studies are valuable in order to understand the interplay of issues between various levels of administration. Thus, to comprehend this issue, more comparative studies that employ various contextual bases need to be undertaken.

Even looking at this crucial point, comparative studies between various levels of government entities, such as studies comparing the accounting systems and practices of federal, state or local governments (the three levels of administration domains) were extremely rare or even non-existent (Christianes, 2001). The majority of those who study this context mainly focus on a single selected administration domain. For example, some focus on central government level (see Garseth, 2011; Lye etal., 2005; Newberry \& Pallot, 2005; Likierman, 2000; Ahikari \& Mellemvik, 2011); others on local government level (e.g. Hoque \& Moll, 2001; Bogt, 2008; Brorstrom, 1998; Harun et al., 2012; Christianes, 2001; Yamamoto, 1999); or on governmental entities (e.g. Mellet \& Williams, 1996; Klumpes, 2001; Scott et al., 2003; Mir \& Rahaman, 2007; Mellet \& Williams, 1997; Hodges \& Mellet, 2003; Christianes \& Wielemaker, 2003); or state government level (e.g. Jagalla \& Weber, 2011; Christianes, 2002).

Only a few studies have performed cross-sectional/comparative studies in this context, such as Luder et al., (2009). They examined and compared the implementation of accrual accounting in local government between several countries (U.K., USA, New Zealand and Australia for central government, and France, Italy and Germany for local government). Also, Connolly \& Hyndman (2006) evaluated resource accounting in Northern Ireland and made a comparison between the federal level and state level in order to ascertain the principal benefits and drawbacks experienced when implementing resource accounting. Another rare example is Marti (2006), who conducted a comparative case study on three pioneer countries (the U.K., Sweden and New Zealand) in order to analyse the accounting treatment of problematic elements of financial statements when introducing accrual budgeting and accounting.

It is important to know what is happening in individual countries, but that does not mean that studies conducted in only one country and/or entity are of little value. Hence, we need to pay more intention to the commonalities and the contrasts across single administration domains. Understanding how the ideas and instruments of accounting and financial management travel internationally, as well as the channels and conduits through which they travel, is crucial in the era of diminishing cross-border barriers (Humprey \& Miller, 2011). Moreover, accrual accounting is still in the process of being operationalised for public services in some countries and it seems to face much greater challenges, with the result that its insertion into local or national settings creates many tensions and points of friction (Lapsley et al., 2009). This suggests that we need to know much more about how and under what circumstances 
accrual accounting as calculating instruments can be assembled and put to work in different levels of the administration context.

Furthermore, there is one more area of study that is significant for future research historically based research or accounting historical analyses (Humprey \& Miller, 2011; van Helden 2005). Based on our analysis, there is little historically based research in public sector accounting. There are a few exceptions, such as Klumpses (2001), who examines the financial accountability implications arising from the adoption of accrual-based budgeting by Australian's pension fund managers from 1888 to 1996, and Scott et al. (2003), who conducted a study to trace the use of cash and accrual accounting in the financial reports of two public hospitals in New South Wales between 1857 and 1975. However, conducting this kind of research is not a matter of adhering to esoteric or antiquarian concerns, as the 'new' accounting history has so strongly demonstrated (Hoper et al., 1991). It is more a matter of pursuing the understanding of the conditions of transformation in ways of governing economic and social life that have been taking place over the past two decades and more, and which are in the process of being transformed further (Humprey \& Miller, 2011).

As Pollit (2008) has suggested, we need to attend to the importance of reinstating and understanding the past, as well as the present, of all those processes and institutions that have shaped what we know today as the public sector. The relevance of historical studies of such changes is that they can help us understand how and where the solutions currently being proffered emerged, and in the process can drive away much of their apparent self-evidence and diminish their taken-for-grantedness (Humprey \& Miller, 2011). This is not a matter of expecting historical analyses to tell us to what to do in any specific contexts, but is rather the fact that historical studies of accounting and financial management practices in varied public sector and public service contexts can assist us with locating them within the broader shift in the management of the economic and social relations within which they are embedded (Humprey \& Miller, 2011).

\section{Conclusion}

Following van Helden and Northcott's (2010) method of study for classifying themes, this study analyses published public sector's accrual accounting papers according to van Helden and Northcott's (2010) research objectives, aiming to highlight the possible contextual and applications gaps that can be derived. The findings reveal that research objective (D) was the most popular subject among the researchers, followed by research objective (B). Research objective (C) is usually chosen as a complimentary focus, along with the two previous research objectives being mentioned earlier. On the other hand, most of the papers are less directed towards research objective (A). Although the analysis of publications shows a vibrant research community in PSA using a broad set of methodologies and topics, there are still some major issues of concern. Future research may focus on accrual accounting development research in the public sectors of developing countries, as well as conducting cross-sectional or comparative studies between different levels of governmental agencies to provide valuable understanding of the interplay of issues between various levels of administration. Finally, future research may also explore the historical studies of accrual 
accounting and financial management practices in varied public sector contexts.

\section{Acknowledgement}

The authors acknowledge the financial support of the Universiti Malaysia Sabah's SBK fund (0197-SS-2015/The Implementation of Accrual Accounting System among Public Sector: Comparative Study between Federal Level and Sabah's State Level).

\section{References}

Helden, G. J. V. and Northcott, D. (2010). Examining the Practical Relevance of Public Sector Management Accounting Research. Financial Accountability \& Management, 26(2), 213-241. https://doi.org/10.1111/j.1468-0408.2010.00499.x

Helden, G. J. V. (2005). Researching Public Sector Transformation: The Role of Management Accounting. Financial Accountability \& Management, 21(1), 99-134. https://doi.org/10.1111/j.0267-4424.2005.00211.x

Hood, C. (1995). The 'new public management' in the 1980s: Variations on a theme. Accounting, Organizations \& Society, 20(2/3), 93-109. https://doi.org/10.1016/0361-3682(93)E0001-W

Pasukan Pelaksanaan Perakaunan Akruan (2015). Buletin Fokus Akruan Isu No.5 Jan - Mac 2015. Jabatan Akauntan Negara Malaysia. Retrieved from: http://www2.anm.gov.my/PublishingImages/SitePages/default/FOKUS\%20AKRUAN\%20IS U\%205\%202015.pdf

PricewaterhouseCoopers [PwC] (2015). Towards a new era in government accounting and reporting. PwC. Retrieved from: https://www.pwc.com/my/en/assets/publications/towards-new-era-in-govt-accounting-reporti ng.pdf

\section{Appendix}

\section{Papers included in this review and their classifications}

Classification criteria (included in bracket after each paper):

Criterion - research objective:

A. Proposing new financial/management accounting techniques/approaches into public sector's accrual accounting systems (e.g. accrual output based budgeting, performance management and costing);

B. Examining the effectiveness of existing accrual accounting techniques/approaches;

C. Identifying the conditions for the successful/failure implementation of accrual accounting technique/approaches;

D. Knowledge-building in understanding, explaining and critiquing of the adoption and use of accrual accounting techniques/approaches both in theoretically and practically. 
Table 1. Classification of Paper According to Research Objective

\begin{tabular}{|c|c|c|c|c|}
\hline Authors and Title & $\mathbf{A}$ & B & $\mathbf{C}$ & $\mathbf{D}$ \\
\hline $\begin{array}{l}\text { Adhikari, P. and Mellemvik, F. (2011), 'The rise and fall of accruals: a case of } \\
\text { Nepalese central government' }\end{array}$ & & $\sqrt{ }$ & & $\mathrm{X}$ \\
\hline $\begin{array}{l}\text { Arnaboldi, M and Lapsley, I. (2009), 'On the Implementation of accrual } \\
\text { accounting: A study of conflict and ambiguity' }\end{array}$ & & $\sqrt{ }$ & & $\mathrm{X}$ \\
\hline $\begin{array}{l}\text { Barton, A.D. (2004), 'How to Profit from Defense: A Study in the } \\
\text { Misapplication of Business Accounting to the Public Sector in Australia' }\end{array}$ & & $\mathrm{X}$ & & $\sqrt{ }$ \\
\hline $\begin{array}{l}\text { Bogt, H.J. ter, (2008), 'Management Accounting Change and New Public } \\
\text { Management in Local Government: A Reassessment of Ambitions and Results } \\
\text {-An Institutionalist Approach to Accounting Change in the Dutch Public } \\
\text { Sector' }\end{array}$ & & $\sqrt{ }$ & & $\mathrm{X}$ \\
\hline $\begin{array}{l}\text { Brignall, S. and Modell, S. (2000), "An institutional perspective on } \\
\text { performance measurement and management in the "new public sector" }\end{array}$ & & & & $\sqrt{ }$ \\
\hline $\begin{array}{l}\text { Broadbent, J., Jacobs, K., \& Laughlin, R. (1999), 'Comparing schools in the } \\
\text { UK and New Zealand: individualizing and socializing accountabilities and } \\
\text { some implications for management control' }\end{array}$ & & $\mathrm{X}$ & & $\sqrt{ }$ \\
\hline $\begin{array}{l}\text { Broadbent, J., Jacobs, K., \& Laughlin, R (2001), 'Organisational Resistance } \\
\text { Strategies to Unwanted Accounting and Finance Changes: The Case of } \\
\text { General Medical Practices in the U.K' }\end{array}$ & & & $\sqrt{ }$ & $\mathrm{X}$ \\
\hline $\begin{array}{l}\text { Broadbent, J. and Laughlin R. (2002), 'Accounting Choices: Technical and } \\
\text { Political Trade-Offs and the U.K's Private Finance Initiative' }\end{array}$ & & $\mathrm{X}$ & $\sqrt{ }$ & \\
\hline $\begin{array}{l}\text { Broadbent, J. and R. Laughlin (2003), 'The Role of PFI in the UK's } \\
\text { Government Modernization Agenda' }\end{array}$ & & $\mathrm{X}$ & $\sqrt{ }$ & \\
\hline Brorstrom, B. (1998), 'Accrual Accounting, Politics and Politicians' & & & $\sqrt{ }$ & $\mathrm{X}$ \\
\hline $\begin{array}{l}\text { Connolly, C. and Hyndman, N. (2006), 'The actual implementation of accruals } \\
\text { accounting caveats from a case within the UK Public Sector' }\end{array}$ & & $\mathrm{X}$ & $\sqrt{ }$ & \\
\hline $\begin{array}{l}\text { Christianes, J. and Rommel, J. (2008), 'Accrual Accounting Reforms: Only } \\
\text { for Businesslike (Parts of) Governments' }\end{array}$ & & $\sqrt{ }$ & & $\mathrm{X}$ \\
\hline $\begin{array}{l}\text { Christianes, J. and Wielemaker, E. D. (2003), 'Financial Accounting reform in } \\
\text { Flemish Universities: An Empirical study of the implementation' }\end{array}$ & & $\mathrm{X}$ & $\sqrt{ }$ & \\
\hline $\begin{array}{l}\text { Christianes, M. (2002), 'Accrual accounting in the Public Sector: The case of } \\
\text { New South Wales government' }\end{array}$ & & & $\sqrt{ }$ & $\mathrm{X}$ \\
\hline $\begin{array}{l}\text { Christianes, J. (2001), 'Converging new public management reforms and } \\
\text { diverging accounting practices in Flemish local governments' }\end{array}$ & & $\sqrt{ }$ & $\sqrt{ }$ & $\mathrm{X}$ \\
\hline $\begin{array}{l}\text { Doolin, B. (1999), 'Casemic Management in a New Zealand Hospital: } \\
\text { Rationalization and Resistance' }\end{array}$ & & $\sqrt{ }$ & & $\mathrm{X}$ \\
\hline $\begin{array}{l}\text { Edwards, P., Ezzamel M., Mclean C. and Robson K. (2000), 'Budgeting and } \\
\text { Strategy in Schools: the Elusive Link' }\end{array}$ & & $\mathrm{X}$ & $\sqrt{ }$ & \\
\hline $\begin{array}{l}\text { English, L. (2003), 'Emasculating Public Accountability in the Name of } \\
\text { Competition: Transformation of State Audit in Victoria' }\end{array}$ & & $\sqrt{ }$ & $\sqrt{ }$ & $\mathrm{X}$ \\
\hline $\begin{array}{l}\text { English, L.M. and Guthrie J. (2003), 'Driving Privately Financed Projects in } \\
\text { Australia: What Makes the Thick' }\end{array}$ & & & $\sqrt{ }$ & $\mathrm{X}$ \\
\hline
\end{tabular}


Ellwood, S. and Newberry S. (2007), 'Public Sector accrual accounting: Institutionalizing neo-liberal principals'

Garseth, L. (2011), 'Accrual accounting representations in the public sector A case of antopoiesis'

Guthrie, J. (1998), 'Application of accrual accounting in the Australian Public Sector: Rhetoric or reality'

Harun, H., Peursem, K. V. and Eggleton I. (2012), 'Institutionalization of Accrual Accounting in the Indonesian Public Sector'

Hepworth, N. (2003), 'Preconditions for successful implementation of accrual accounting in central government'

Hodges, R. and Mellett, H. (2003), 'Reporting Public Sector Financial Result' Hoque, Z. and Moll, J. (2001), 'Public Sector reforms implications for accounting, accountability and performance of state-owned entities -Australia Perspective'

Humphrey, C. and Miller, P. (2012), 'Rethinking impact and redefining responsibility: The parameters and coordinates of accounting and public management reforms'

Jagalla, T., Becker, S.D. and Weber, J. (2011), 'A Taxonomy of the Perceived Benefits of Accrual Accounting and Budgeting: Evidence from German States'

Jones, L. R. and Kettl, D.F. (2003), 'Assessing Public Management Reform in an International Context'

Klumpes, P. (2001), 'Generalization Accountability of Public Sector management - A case study of the State Authorities Superannuation Board of New South Wales'

Lande, E. (2005, May $26^{\text {th }} \& 27^{\text {th }}$. 'Accrual Accounting in the Public Sector: Between Institutional Competitiveness and Search for Legitimacy' Lapsley, I. (2001), 'Accounting, Modernity and Health Care Policy' Lapsley, I. and Oldfield R. (2001), 'Transforming the Public Sector: Management Consultants as Agents of Change'

Lapsley, I. and E. Wright (2004), 'The Diffusion of Management Accounting Innovations in the Public Sector'

Lapsley, I., Mussari, R. and Paulsson, G. (2009), 'On the adoption of accrual accounting in the public sector: A self-evident and problematic reform'

Likierman, A. (2000), 'Changes to managerial decision-taking in U.K. central government'

Luder, K. (2000), 'National Accounting, Governmental Accounting and Cross-Country Comparisons of Government Financial Condition'

Lye, J., Perera, H. and Rahman, A. (2005), 'The evolution of accruals based crown (government) financial statements in New Zealand'

Marti, C. (2006), 'Accrual Budgeting: Accounting Treatment of Key Public Sector Items and Implications for Fiscal Policy'

Mellett, H. (1997), 'The role of resource accounting in the U.K government's

\begin{tabular}{|l|l|c|c|}
\hline & & $\sqrt{ }$ & $X$ \\
\hline
\end{tabular}

\begin{tabular}{|l|l|l|l|} 
& & & $X$ \\
\hline & $\sqrt{ }$ & $\sqrt{ }$ & $X$ \\
\hline
\end{tabular}

\begin{tabular}{|l|c|c|c|} 
& $\sqrt{ }$ & $\sqrt{ }$ & $\mathrm{X}$ \\
\hline
\end{tabular}

\begin{tabular}{|l|l|c|c|}
\hline & & $V$ & $X$ \\
\hline & & $X$ & \\
\hline
\end{tabular}


quest for 'Better Accounting"

Mellet, H. and Williams, J. (1996), 'Accountability and the accounting regime in the public sector: Some message from the NHS'

Mir, M.Z., and Rahaman, A.S. (2007), 'Accounting and Public Sector Reforms -A study of a continuously evolving governmental agency in Australia'

Newberry, S. and Pallot, J. (2005), 'A Wolf in Sheep's Clothing? Wider Consequences of the Financial Management System of the New Zealand Central Government'

Pallot, J. (2001), ‘A Decade in Review: New Zealand's Experience with Resource Accounting and Budgeting'

Pallot, J. (1999), 'Beyond NPM: Developing Strategic Capacity'

Potters, B. (2002), 'Financial accounting reforms in the Australian Public Sector: An episode in institutional thinking'

Robinson, M. (1998), 'Accrual Accounting and the Efficiency of the Core Public Sector'

Scott, J.E.M., McKinnon, J.L. and Harrison G.L. (2003) 'Cash to accrual and cash to accrual: A case study of financial reporting in two NSW hospitals 1857 to post-1975,

Yamamoto, K. (1999), 'Accounting System Reform in Japanese Local Governments'

Note:

' $\mathrm{X}$ ' symbol: indicates the main focus of research

' $\sqrt{ }$ ' symbol: indicates cross-sectional research objective

\section{Copyright Disclaimer}

Copyright for this article is retained by the author(s), with first publication rights granted to the journal.

This is an open-access article distributed under the terms and conditions of the Creative Commons Attribution license (http://creativecommons.org/licenses/by/3.0/). 